\title{
University Libraries in Pakistan
}

The development of university libraries in Pakistan is summarized, with a discussion of the current status of such libraries, including consideration of library organization, resources, organization of collections and cataloging, services to readers, and library staff. Major problems impeding improvement of library service are also discussed -the chief problem one of adequate financial support.

$\mathrm{T}$ HE CONCEPT OF MODERN LIBRARIANSHIP in the territories now constituting Pakistan dates back to 1915 when Asa Don Dickinson, an American librarian, was invited by the University of Panjab to organize its library on modern lines and to teach newer library methods to librarians in the province of Panjab. The institution of such instruction for the first time within the walls of a university in British India may be termed the beginning of the library profession in this part of the world. Similarly, the introduction of several modern methods by Dickinson, while reorganizing the university library, may be called the beginning of academic library service in the subcontinent of India and Pakistan. Some methods introduced included adoption of the Dewey Decimal Classification and introduction of the main entry concept, the card catalog, and the dictionary catalog.

This establishment of a library education program had a great influence on the development of libraries and the library profession in the whole of British India. Alumni of the program found their way to all parts of British India. A number of other significant develop-

Syed Jalaluddin Haider is visiting professor of library science, Faculty of Education, University of Tabriz, Tabriz, Iran. ments took place during this period in the city of Lahore, the site of the University of Panjab: the Panjab Library Association was formed in 1916; the first manual on librarianship, Panjab Library Primer, was published in the same year by the university; the first All India Library Conference was held at Lahore in 1918; and the first professional journal, Modern Librarian, began publication here in 1930.

But, these achievements notwithstanding, the climate for library development in the academic institutions of British India was not favorable. The reason may be found in the textbook-oriented teaching method used by institutions of higher education at that time. Even after independence in 1947 the educational system of British India remained in force. Change occurred only in the 1960s when a new concept-quality in education-began to gain ground. This basic change in educational philosophy brought with it an overall consciousness of the need for improved academic library service. The need for better libraries had also been recognized in the several documents of the provincial and central governments as well as in reports of various national commissions. For example, the report of the Commission on National Education in 1959 stated: "Every college and university should have a library large enough to act as a work- 
room where all students are able to study privately during off periods and outside college hours." Further, emphasizing the importance of the library in the university, it noted: "The library is at the very heart of the idea of the university, and . . . books with which it is stocked, librarians who serve in it, and the kind of use which students make of it should reveal the extent to which it is discharging its real function." 1

Some significant library developments which had an impact on academic library development included: (a) the institution of the Post-Graduate Diploma Course in Librarianship at the University of Karachi (1956); (b) the formation of the Pakistan Library Association (1957) and other professional organizations at the provincial and regional levels; (c) the publication of the Pakistan Library Review (1958) as a professional medium of communication; (d) the establishment of the National Book Center of Pakistan (1961); (e) the institution of the Master's Program in Library Science at the University of Karachi (1962); (f) the enactment of a copyright law (1962); and (g) the establishment of the National Bibliographical Unit (1962).

A number of other general factors may also be cited: (a) the political and economic stability of the country; (b) the tremendous increase in the enrollment of the universities; (c) the establishment of new universities and expansion of older ones; and (d) the changing objective of higher education. To achieve this objective, universities were to provide competent human resources for national development and to undertake research projects to further the economic and social development of Pakistan.

The following survey of university library service in Pakistan and the problems which have retarded the libraries in reaching their fullest potential is based, for the most part, on the observa- tions and experience of this author. ${ }^{2}$

\section{A SURVEY OF UnIVERSITY LIBRARIES}

Excluding the University of Panjab, whose origin dates from 1882, the universities in Pakistan and their libraries are the product of the postindependence period. At present there are eight universities in Pakistan with a total student body of 25,000 students and more than 3,000 faculty members and research staff. All the universities are both teaching and, with the exception of the University of Islamabad and two professional universities, affiliating bodies. In general, the universities in Pakistan are responsible for graduate and postgraduate studies. Usually a general university has arts, science, and other faculties divided into departments for principal subjects. These provide courses in the arts, social sciences, physical sciences, natural sciences, law, medicine, etc. Most of the universities offer research degrees.

\section{Organization}

All universities in Pakistan, with the exception of the University of Baluchistan where the library is in the process of being established, have provision for some kind of library service. The tradition of a central library along with departmental/seminar libraries outside the central organization is the most favored form of structure at present. The only exceptions are the Universities of Karachi and Islamabad. At Karachi collections and services have been brought together in one building. On the other hand, the library at Islamabad has been organized on a decentralized basis, despite the existence of a central library which retains primary responsibility for acquisition and processing of materials.

\section{Resources}

With respect to size of collections, the university libraries in Pakistan are somewhat similar to medium-size college 
libraries in the United States. The Panjab University Library (once enjoying the honor of being the leading university library in the Indo-Pakistan subcontinent) has a collection of $250,000 \mathrm{vol}$ umes, including 18,000 manuscripts in Oriental languages, and is the country's leading library. The next largest is the Karachi University Library, established in 1951. It has a collection of 200,000 volumes, including back runs of periodicals, and 5,000 microforms of rare and out-of-print materials. The University of Sind at Hyderabad, founded a short time before independence, has recently reached a total of 110,000 volumes. The libraries of the Universities of Peshawar (1950) and Islamabad (1965) and the two professional universities (1961) range in size between 75,000 and 100,000 volumes.

The combined resources of all the university libraries in the country total approximately 800,000 volumes. The majority of books, nearly 75 to 80 percent, are in English, primarily American and British publications, followed by books in the national language (Urdu) and other languages (Persian, Arabic, and regional languages). In terms of major disciplines represented in the collections, the scientific and technological subjects are preeminent, followed by the humanities, social sciences, and history.

\section{Organization of the Collections}

For the organization of their resources, the libraries employ the Dewey Decimal Classification with some modifications for Oriental topics, such as Islamic Philosophy, Islam, and Oriental languages, literature, and history. The expansion of the Dewey classification, prepared by M. Shafi in cooperation with the Department of Library Science of Karachi University, is the most widely used.

Both dictionary and classified catalogs are in existence, but the majority do employ a classified catalog. The Anglo-American Cataloging Rules (1967) are followed. Because of the absence of a national cataloging code in a true sense, there are great problems in the cataloging of Oriental materials. Cataloguing of Pakistani Names, by Anis Khurshid, is used by the majority of university libraries for cataloging of publications by Pakistani authors at present. $^{3}$ Generally, a separate catalog, in Arabic script, is maintained for Oriental books.

\section{Services for Readers}

Usual library services include: preparation of bibliographies and list of current acquisitions; interlibrary loan; exchange programs with other libraries and research organizations; maintenance of clipping and pamphlet files; provision of photocopy service and microfilming of rare materials; answering inquiries; help to students in the use of materials; and organization of lectures and exhibitions.

On the basis of observations, it may be concluded that an average Pakistani student makes more use of the library at present than did his predecessor. This may be due to the change in the traditional educational method as well as the improved services offered by the libraries. Like students, the younger members of the faculty, particularly those educated in the United States and Great Britain, use the libraries more frequently and more extensively than did their predecessors. The greatest obstacle to library use is the closed stack system in effect.

\section{The Library Staff}

The importance of a qualified staff as one requirement for the improvement of libraries cannot be overemphasized. There was an acute shortage of qualified manpower in the field in the early years after the birth of Pakistan. For example, the Panjab University Li- 
brary, the largest library in the country, remained without a single professional librarian for many years. But, with the institution of courses leading to the master's degree in library science, there is now no shortage of qualified librarians, at least for secondary positions. Each year there are 150 new holders of the Post-Graduate Diploma and 50 new graduates with the master's degree, and this is sufficient for the time being. But the location of competent individuals to hold top administrative positions is a major problem. For example, the University of Islamabad has not been able to find a suitable university librarian for the past five years. Similar situations are true for the University of Engineering and Technology, Lahore, and the University of Baluchistan, Quetta.

Another manpower problem faced by the academic libraries is the "braindrain." Some of the nation's best librarians have left their jobs and are now working in the United Kingdom, Canada, Nigeria, Libya, Saudi Arabia, and Iran. Others are trying to leave the country for better opportunities elsewhere. This is primarily because of the low salaries and low status attached to this profession, despite the best efforts of librarians and their professional organizations. However, in the Education Policy, announced by the government in March 1972, granting of faculty status has been recommended for the first time to the professional staff working in academic libraries. ${ }^{4}$ But for a number of reasons the recommendation has not been implemented in full.

\section{Physical Facilities}

The existing university libraries, with the exception of those at Peshawar, Karachi, and Sind, do not have their own permanent buildings. This remains one of the major obstacles to the expansion and introduction of modern and newer services. This need has been felt particularly in recent years, and new library buildings are included in the master plans for the new campuses at some universities. It is expected that within the next ten years all university libraries will have their own permanent quarters.

\section{Major Problems}

University libraries in Pakistan face a number of problems, and the following are the most significant.

\section{Inadequacy of Collections}

In recent years the university libraries have come to feel the inadequacy of their resources to meet the needs of the growing instructional and research programs of the universities. The evaluation of the collections in certain subjects, even at the universities with the largest collections, by students in the M.A. course in library science, has revealed the existence of obsolete materials, unnecessary duplication of titles, and gaps in periodical holdings. The coverage of current periodical literature presents a more gloomy picture; for example, the Karachi University Library has the largest periodical list-1,200 titles; whereas other libraries receive from 200 to 700 titles.

\section{Dearth of Textbooks}

In advanced countries students are expected to purchase their own textbooks, but in Pakistan the students cannot afford to do so because of their poverty. Therefore, libraries are compelled to allocate a portion of their meager budgets for this purpose. In answer to this problem, the Karachi University Library, with the financial assistance of the Asia Foundation, established the Book-Bank Service in 1964. Through this service books are lent to students for the entire academic year at a nominal charge. The example furnished by Karachi has been followed at Panjab and Peshawar.

\section{Difficulties in Acquisitions}

Due to low book production and the absence of an organized book trade in the country, libraries in Pakistan buy 
about 70 percent of required books from abroad-either directly as in the case of university and research libraries, or for college and other small libraries through local booksellers. Problems encountered include nonavailability of selection aids, import restrictions, postal and customs formalities, and conversion rates if procured through local booksellers.

In procuring books produced locally, main problems include absence of selection aids, nonappearance of the current national bibliography regularly, and the lack of subject bibliographies and publishers' catalogs.

\section{Financial Support}

This is the most serious problem at the present time because of the country's own economic problems during the last several years. The absence of sufficient funds has badly affected the quality of resources, particularly in the procurement of books from abroad.

A comparison of figures for university libraries reveals that usually the amount allocated for the library in the universities ranged between 100,000 and 250,000 rupees (approximately $\$ 10,000$ to $\$ 25,000$ U.S.). This sum does not include library salaries. In some universities there is no separate budget for the library; instead, it forms a part of "the publications fund" for the institution.

\section{Interinstitutional Cooperation}

The importance of library cooperation in a developing country like Pakistan cannot be overemphasized; but, with the exception of interlibrary loan, there is no cooperation. Even the operation of interlibrary loan on a wider scale has been impeded because of the absence of a union catalog and an interlibrary loan code. The major areas for cooperation among libraries at the present are: cooperative acquisitions based on subject specialization (with particular reference to acquisition of periodicals) among university libraries; compilation of a union catalog and union list of serials; development of a storage center for manuscripts and rare books; and the establishment of bibliographical centers at regional levels.

\section{ConcLusion}

Despite all their limitations, university libraries in Pakistan are in better condition than other types of libraries. The chief deterrent to their development has always been the lack of money. The improvement of library service in Pakistan is more closely linked to the country's economy than in any other developing country. However, with the economic reforms introduced in the country within the last two years, it is hoped that conditions will improve. Another step taken by the present government, which may mean improvement and expansion in library service, was the issuance of the Education Policy in March 1972. This policy covers many areas related to library services and library resources; and one may hope that, along with the general improvement and expansion in the educational and research facilities in the country, university libraries in Pakistan will also face a better future.

\section{REFERENCES}

1. Pakistan Ministry of Education, Report of the Commission on National Education (Karachi: Manager of Publications, 1960), p.65.

2. Syed Jalaluddin Haider and Akthar Hanif, "University Libraries," in Studies in Pakistan Librarianship (Karachi: Librarians Forum, 1971), p.29-42. Syed Jalaluddin Haider, "Science-Technology Libraries in Pakistan,"
Special Libraries 65:474-78 (Oct./Nov. 1974).

3. Anis Khurshid, Cataloguing of Pakistani Names (Karachi: University of Karachi Library Science Dept., 1964).

4. Pakistan Ministry of Education, The Education Policy, 1972-1980 (Islamabad: The Ministry, 1972). 